\title{
PROBLEMS AND SOLUTIONS OF THE RESEARCH TRAVEL FOR TEENAGERS IN LESHAN CITY
}

\author{
Lishan $\mathrm{Xu}^{*}$ \\ Leshan Normal University, Leshan 614000, China \\ *Corresponding Author E-mail: $420406106 @ q q . c o m$
}

This is an open access article distributed under the Creative Commons Attribution License, which permits unrestricted use, distribution, and reproduction in any medium, provided the original work is properly cited.

\section{ARTICLE DETAILS}

\section{Article History:}

Received 26 July 2019

Accepted 29 August 2019

Available online 09 October 2019

\section{ABSTRACT}

More and more attention has been paid to the research travel activities of teenagers. Based on an overview of the current situation of research travel of teenagers in Leshan City, this paper analyses its main problems and the causes, and tries to put forward some countermeasures and suggestions to improve the research travel for young people in Leshan City.

\section{KEYWORDS}

Teenagers, Research Travel, Countermeasures and Suggestions.

\section{AN OVERVIEW OF THE RESEARCH TRAVEL FOR TEENAGERS IN LESHAN CITY}

In recent years, with the continuous improvement of people's material and cultural level, people have a new understanding and pursuit of teenagers' spiritual civilization construction and comprehensive quality and ability training. Parents of primary and secondary school students pay more attention to injecting practical experience and learning into their children's healthy growth process. In 2016, the Ministry of Education and other relevant departments issued a file named "Opinions on Promoting the Research travel of Primary and Secondary School Students", which explicitly stipulates that the research travel should be included in the Education and Teaching Plan of these schools. According to the specific spiritual requirements of the file and the actual market conditions, Leshan Education Bureau and other departments issued the "Opinions on the Implementation of Promoting Research travel for Primary and Secondary School Students", which makes the education and teaching plan of carrying out research travel for primary and secondary schools more specific [1]. Through visiting some elementary and secondary schools in Leshan City, it is found that the school can organize students to take part in research travel activities on various themes in accordance with the spirit of the file, such as the theme of "reading ten thousand books, traveling ten thousand miles". Some schools entrust the travel agency with the task of outsourcing all the research travel activities, so that the travel agency is fully responsible for the formulation of activities, research content and itinerary arrangements. For example, in 2017, Leshan Foreign Language Primary School organized a research travel in Shanghai for the sixth grade of primary school, which was commissioned by a travel agency to tailor it. In some schools, teachers form mentor group for the research travel. They collect relevant information with students, study and formulate research contents, activities and objectives, and organize and carry out research activities by themselves. For instance, the County Street Primary School in Leshan carrying out a research travel of red culture, visiting the Jianchuan Museum in Dayi, Chengdu in 2018 [2].

The author interviewed and consulted some parents of students in primary and secondary schools at random and found that most parents agreed with and fully supported the school to organize meaningful research travel activities. One parent pointed out that the rich and colorful research activities are conducive to young people's close contact with nature and society, so that children can better learn the knowledge that cannot be learned and experienced in textbooks in a relaxed and happy environment. One of the parents felt that after his child participated in the school's research travel activities, the child's vision of learning was broadened, and the learning state changed dramatically, from passive learning to active learning [3]. But there are also parents who have objections to the research activities of primary and secondary school students. They mainly believe that the number of students participating in each activity is large, and the pressure of the school in student management and security is great. Besides, the number of teachers leading the team is very limited, and the students' knowledge of emergency selfhelp is weak. In view of the above reasons, the personal safety of students cannot be protected [4].

In addition, the author got to know that the earliest travel agency in Leshan City to do research travel planning is China Travel. They focus on creating excellent research tours in surrounding areas. For example, the parentchild summer camp, the Fairy Tales Travel Camp in Emei Mountain is of the popularization of science. Its theme is "Pursuing Fireflies and Lighting Midsummer Nights", and parents and children can be close to nature to better understand the life habits of fireflies. The study tour of the Root Calligraphy Art Museum is mainly to experience the vastness and profundity of Chinese characters, so as to enhance students' cultural selfconfidence, inherit national culture and experience national spirit. At the same time, it can also tailor-made out-of-town or overseas research travel activities. Most travel agencies in the survey take orders locally and then outsource them to large travel agencies to earn the profit difference. Local travel agencies are only responsible for charter business, while the travel agencies in the destination are responsible for the planning of the whole activity, as well as the formulation and implementation of the specific learning content [5].

Furthermore, the author conducted a random survey on some teenagers in Leshan Central District. On the one hand, most of the students said they enjoyed the school's research travel. Not only can they truly and vividly feel some knowledge, customs and feelings mentioned in books, but also, they can broaden their horizons and cultivate the team consciousness and cooperation ability in this process. It is an indispensable "classroom" for students to grow up. On the other hand, some students also said that the content of research travel organized by the school is single, and there are fewer research bases around the district. The integration of research and learning is not high, and the feeling of activity experience is not good, so it cannot really improve their self-ability. Some students also resent the fact that the school requires every student to write social practice reports and other related learning tasks after a research travel.

\section{PROBLEMS AND SOLUTIONS OF YOUTH RESEARCH TRAVEL IN} LESHAN CITY

\subsection{There are few key research bases with local characteristics}

Leshan is the preferred city for tourism in Sichuan. There are many scenic spots for young people to do research travel, such as Leshan Grand Buddha, Emeishan Scenic Spot, the Former Residence of Guo Moruo, 
Jiayang Train, Thousand Buddha Rock, and the Research Base to learn ancient papermaking, etc. Up to now, the first batch of provincial practical education bases for primary and secondary school students in Sichuan Province have been officially released, including Nongfu Spring Industrial Tourism Zone in Emei, the Former Residence of Guo Moruo and Suji Silkworm Breeding Farm. The first batch of practical education bases for elementary and middle school students in Leshan City officially issued are: Jiayang Mining Museum, Jinkouhe Railway Military Museum, Emeishan Museum, Martyrs Memorial Park in Leshan Bamboo Garden , Confucius' Temple in Qianwei, Sichuan Root and Stone Art Museum, Zhuangyuan Calligraphy and Painting Paper Factory in Jiajiang County, National Museum of Nuclear Fusion in the School of Engineering and Technology of Chengdu University of Technology, and Leshan Museum.

These research bases can basically ensure the normal operation of the research travel for young people. However, the local characteristics of these research travel bases are not obvious enough, the integration degree is not high, and the purpose of carrying out research travel activities is not strong. Thus, it is impossible to tailor a systematic and targeted program for young people, which results in a great discount of the effectiveness of the research travel. Besides, there are a large number of young people who need to participate in research travel activities, and the reception of key research and practical education bases at provincial and municipal levels is far from meeting their needs. In addition, many research travels base still lack information consultation channels and populating platforms, and the participation and support of local governments and related industries are insufficient, resulting in low social awareness. They are unable to attract more teenagers to "do research travel", which also seriously restricts the admission of teenagers from other cities to do research travel in group.

\subsection{The content of research is single, lacking the content of moral and} aesthetic education.

Through the understanding of the development of research travel in some primary and secondary schools in Leshan City and the investigation of some local research bases, it is found that the curriculum design of research travel is uneven, the form is single, the depth of learning is not enough, and the goal of guiding education is not clear. Most of the research activities organized by the school are to lead students to visit the base collectively, listen to the guides' explanations, and give a hurry and cursory glance by the students themselves. There is no more substantial learning content and lack of integration of moral and aesthetic education. Students cannot experience in depth, so it is difficult to improve their comprehensive quality and ability.

The Former Residence of Guo Moruo in Leshan City mainly commemorates the great literary giant, Mr. Guo Moruo. When students carry out research tours, they mostly retrospect Guo Moruo's growing footprints in his youth, neglecting to excavate the moral education content worthy of learning from Mr. Guo Moruo. Besides, the whole memorial hall is the traditional architectural style of residents in Western Sichuan. However, the research tour does not integrate aesthetic education while experiencing Mr. Wang's romantic and poetic humanistic temperament. In terms of Sichuan Suji Silkworm Breeding Farm, it helps students understand the life and the culture of silkworm, making students experienced the whole process of silkworm rearing. It just mainly focuses on popularizing science knowledge among teenagers. The main reasons for the single content are the lack of awareness of the curriculum design of research travel, the lack of coordination between the historical background of the base and the content of moral education and aesthetic education, and the lack of overall design of the curriculum, which results in the little effect of research travel.

\subsection{Most of the research travel groups are outsourced, lacking perfect} supervision system.

In recent years, all elementary and secondary schools in Leshan City have incorporated research travel into their educational and teaching plans and attach great importance to the implementation and promotion of this work. Through the investigation and research of some primary and secondary schools in urban areas, it is found that students in primary school basically carry out research travel activities around the city; students in secondary school mainly carry out it around Chengdu and coastal cities, and a few qualified students participate in overseas research travel activities; and students in senior high school mainly carry out it in coastal cities and abroad. Some research travels are organized by the school or entrusted by the school. Some are registered and participated in the external teaching institutions by the parents of the students, and accordingly the forms of the research travel are more diversified. However, due to the different understanding of research travel in different schools, the development situation and effectiveness are uneven. Some schools are earnestly promoting the implementation of this work to ensure that students really learn and gain in this process. But some schools just stay on the surface. They arrange activities in a hurry and send students out for a day, not asking whether the students have harvested. All they want to do is to just write a news report and complete the work perfunctorily.

Meanwhile, the author also finds that the higher authorities have provided guidance for the school to carry out research travel activities, but there is insufficient supervision over the program, schedule and effectiveness. The plans of the research activities of schools only need to be submitted to the higher education administration department for the record in advance. In addition, some schools entrust other institutions to carry out research travel activities. They clearly stipulate to cooperate with qualified, reputable entrusted enterprises or institutions, and clearly entrusted to them to bear relevant responsibilities. However, there are many institutions in the market under the guise of "research travel" lacking the accreditation criteria of admission management. It is difficult to judge the quality of institutions' qualifications, so it is hard to provide better safety and quality guarantee for research travel.

\section{SUGGESTIONS ON IMPROVING THE RESEARCH TRAVEL FOR} TEENAGERS IN LESHAN CITY

3.1 Develop characteristic research bases based on local conditions and do a good job in the construction of research bases.

Research travel bases mainly refer to popular science venues, museums, quality education bases, modern industrial and agricultural bases, red patriotic education bases, etc., which can provide research content and research sites for research travel. Just as the old Chinese saying goes, reading ten thousand books and traveling ten thousand miles. The research travel base is an important guarantee for the successful development of research travel activities. According to the "Opinions on Promoting the Implementation of Research Travel for Primary and Secondary School Students" issued by Leshan City, it is clearly pointed out that the construction of research travel base should combine local conditions, school conditions and students' conditions, rely on natural and cultural heritage resources, and build a number of demonstration excellent research travel routes. Combining with the actual situation of the existing natural and human resources, people should try to polish and excavate the research base with local characteristics. For example, when Wutongqiao District is making efforts to take advantage of red tourism resources, it should focus on the building of Ding Youjun Memorial Hall and the old site of Yonglichuan Factory to refine and integrate the research base with irreplaceable cultural and spiritual inheritance characteristics. The construction of new development bases and the maintenance of existing bases should be strengthened. With the gradual increase of the number of participants in research travel, the demand for research bases is increasing, so is the access requirements. Relevant higher authorities should strictly control the quality of the new research base, and strictly implement the admission criteria of the research base. They can implement the management system of multi-party field visits and comprehensive evaluation and acceptance, making students experience deeply before acceptance and examination. In addition, repair and maintain the existing research bases and appeal for more social forces to invest in the work. At the same time, gradually establish an annual assessment system for the research base. Unqualified research travel bases are resolutely banned, and one-vote veto system is applied to the bases that have potential safety hazards and are not improved.

\subsection{Strengthen the training of teachers and further promote the} integration of moral and aesthetic education.

The main purpose of research travel is to better cultivate students' core literacy. It is a comprehensive off-campus practical activity for teenagers to "study while travel". It is not only experiential education, but also quality education. In the above official file, it is pointed out that the education of ideal and belief, patriotism, revolutionary tradition and national conditions should be taken as important carriers, and the research travel of different academic sections should be developed in a targeted way. Course design is the most important core element of research travel. The reform of the content of research courses should be firmly promoted and the course design of "I have visited here" should be resolutely resisted. In the primary school, which mainly focuses on local conditions, they should try to integrate the content of moral education and aesthetic education, such as the construction of new countryside, the reform of grass-roots system and so on, while returning to the experience of rural life. In the secondary school which takes conditions of the county and the city as the main factors, they need to dig out the long history of 
national development, excellent revolutionary moral tradition, integrate moral and aesthetic education, transfer positive energy for students, and help students form correct outlooks on world, life and values.

Continue to strengthen the training of research travel instructors. Research travel instructor is the soul of leading students to complete the research travel. First of all, relevant departments should continuously strengthen investment in training funds for research travel tutors, and build a group with strong professional quality and ability. Secondly, the instructors who are especially responsible for the research travel work should receive professional and standardized training, and they must pass the training and assessment before they can take up their posts to guide students' research activities. Finally, the research instructor should comb and design the research education curriculum according to the actual situation of the research base, so that students can consciously accept moral and aesthetic education while experiencing different natural and human environments, so as to comprehensively improve the comprehensive quality of primary and secondary school students.

\subsection{Strengthen the implementation system of supervision and responsibility to escort the research travel activities}

In the process of research travel, the most important concern is security. Educational authorities and schools are the first person responsible. Responsible managers should strengthen the examination and verification of school research travel programs and emergency plans. In the process of carrying out the activities, they should make their respective responsibilities more detailed, implement them to departments and specific responsible persons, and put an end to management vacancies and gaps. At the same time, before the start of the research travel, the school should ensure that every teacher and student involved in the activities have bought insurance, and the insurance has come into effect. Schools should sign safety responsibility letters with outside institutions and students' parents to clarify the safety responsibilities of all parties. Schools should do a good job of safety education and guidance to the teachers and students participating in the activities, and exhort them to take safety as the first, improving the safety awareness of teachers and students.
In addition, the education department, together with other professional and technical management departments, should establish a set of standardized accreditation standards, service management standards, departments and market supervision system. For example, the tourism administration department shall be responsible for formulating market access conditions and service standards for enterprises or institutions conducting research travel, and for identifying and technical checking the qualifications of the entrusted institutions. Traffic management departments are mainly responsible for supervising and assuming the safety of transport vehicles. The insurance department is mainly responsible for the supervision of the insurance liability of teachers and students, as well as other related products. Relevant management departments, social forces and the market work together to supervise the whole process of research travel, so as to ensure the research travel activities can really be implemented safely and protect students to make them keep their mind on their studying.

\section{REFERENCES}

[1] Huang, J.J. 2014. How to "Research" and "Travel" in A "Research Travel"?, (2016-12-28). Om/a/20140709/41079785_0.shtml.

[2] Liu, L. 2018. Progress and Reflection of Research Travel in Primary and Secondary Schools. Educational Exploration, (1).

[3] Li, C.Z. 2018. Research-Based Study Tourism: Implementation Predicament and Solutions. Educational Science Research, (9).

[4] Shi, H.B. 2018. A Summary of the Significance and Countermeasures of Developing Research Tourism. Jiangsu Commercial Forum, (10).

[5] Shi, Y.L. 2019. Research on the Implementation of Research Travel in Primary School. Hebei Normal University. 